\title{
Interleukin-6 stimulation of growth of prostate cancer in vitro and in vivo through activation of the androgen receptor
}

\author{
Kamilla Malinowska ${ }^{1}$, Hannes Neuwirt ${ }^{1}$, Ilaria T Cavarretta ${ }^{1}$, Jasmin Bektic ${ }^{1}$, \\ Hannes Steiner ${ }^{1}$, Hermann Dietrich ${ }^{3}$, Patrizia L Moser ${ }^{2}$, Dietmar Fuchs ${ }^{4}$, \\ Alfred Hobisch ${ }^{5}$ and Zoran Culig ${ }^{1}$
}

\author{
${ }^{1}$ Department of Urology ${ }^{2}$ Department of Pathology ${ }^{3}$ Laboratory Animal Facilities and ${ }^{4}$ Division of Biological Chemistry, Biocenter, \\ Innsbruck Medical University, Anichstrasse 35, A-6020 Innsbruck, Austria \\ ${ }^{5}$ Department of Urology, General Hospital Feldkirch, Feldkirch, Austria \\ (Correspondence should be addressed to Z Culig; Email: zoran.culig@i-med.ac.at)
}

\begin{abstract}
It is hypothesized that ligand-independent activation of the androgen receptor is one of the mechanisms implicated in tumour progression. However, supportive evidence is limited to the effect of HER-2/neu that stimulates prostate cancer progression through activation of the androgen receptor. In the present study, we have asked whether the proinflammatory cytokine interleukin-6 (IL-6), which is known to stimulate androgen receptor activity and expression of its downstream target genes, may also induce growth of androgen-sensitive cells. We have found that IL- 6 differentially regulates proliferation of LAPC-4 and MDA PCa $2 b$ cells. In MDA PCa $2 b$ cells, growth stimulation by IL- 6 was reversed by administration of either the non-steroidal anti-androgen bicalutamide or the inhibitor of the mitogen-activated protein kinase pathway PD98059. Neither cell line was found to express endogenous IL-6. Interestingly, the treatment of those prostate cancer cells did not increase phosphorylation of STAT3. The effect of IL-6 on stimulation of androgen receptor activity in MDA PCa $2 b$ cells was lower than that of androgen, comparable with findings reported by other researchers. However, growth of MDA PCa $2 \mathrm{~b}$ xenografts in castrated animals treated with IL- 6 was similar to that in non-castrated animals. In addition, bicalutamide showed an inhibitory effect on IL-6-regulated growth in vivo. Taken together, data in the present study demonstrate that IL- 6 may cause growth of androgen receptorpositive tumours in vitro and in vivo through activation of the androgen receptor.
\end{abstract}

Endocrine-Related Cancer (2009) 16 155-169

\section{Introduction}

Prostate cancer whose growth is regulated largely through activation of the androgen receptor (AR) is the most common malignancy in the western world in men. Most small tumours detected by prostate-specific antigen (PSA) screening are nowadays cured by radical prostatectomy and radiation therapy. By contrast, patients with non-organ-confined tumours receive palliative treatment with androgen ablation or blockade of the AR (Huggins et al. 1941). This therapy is effective for an average of 3-5 years before tumours regrow and metastasize to bone and visceral organs.

The AR is a ligand-mediated transcription factor that belongs to the superfamily of steroid receptors. They have similar structures containing the N-terminal domain (NTD) that harbours activation function-1 (AF-1), the DNA-binding domain, hinge region and the ligand-binding domain (LBD) in which AF-2 is located. After ligand binding, the complex between a ligand and receptor is formed. Following translocation to the nucleus, the ligand-AR complex binds to specific androgen response elements, interacts with coactivators and modulates the expression of androgenregulated genes.

Several mechanisms implicated in prostate cancer progression are AR-related. They involve AR gene amplification and overexpression, mutations or ligandindependent activation. A number of mutations in AR 
gene are located in the LBD (Marcelli et al. 2000, Buchanan et al. 2001) and are responsible for broadened ligand specificity. For example, mutated AR $\mathrm{Met}^{715}$ and $\mathrm{Ala}^{877}$ are increasingly activated by adrenal androgens, androgen metabolites, oestrogenic steroids, progesterone and flutamide (Culig et al. 1993, Suzuki et al. 1993).

It is established that, either in the absence of ligands or in the presence of low androgenic concentrations, AR can be stimulated by growth factors, proinflammatory cytokines (Culig et al. 1994, Hobisch et al. 1998, Chen et al. 2000), forskolin (Nazareth \& Weigel 1996, Wang et al. 2006), bombesin (Lee et al. 2001) or HER2/neu (Craft et al. 1999). One of the cytokines whose serum levels are elevated in patients with refractory prostate cancer is interleukin-6 (IL-6). It is a $28 \mathrm{kDa}$ protein that belongs to the IL-6 type cytokines family. It has an effect on cell proliferation, apoptosis and angiogenesis through activation of Janus kinase (Jak)signal transducer and activators of transcription (STAT) factor 3 (Heinrich et al. 2003), mitogenactivated protein (MAP) kinase (Ernst et al. 1996) and phosphoinositol 3-kinase (PI3-K)-Akt (Chen et al. $1999 a, b)$ signalling pathways. IL-6 can affect the growth of prostate cancer cells in a paracrine and autocrine manner. Previous experimental work investigating the ability of IL-6 to induce AR transactivation revealed enhanced expression of an androgen-sensitive reporter gene caused by IL- 6 that was inhibited by the non-steroidal anti-androgen bicalutamide (Hobisch et al. 1998). Although, many studies have been performed to analyze the mechanisms of AR ligandindependent activation, its functional relevance for tumour growth is still under investigation. It was demonstrated by Craft et al. (1999) that cross-talk between HER-2/neu, a member of the epidermal growth factor (EGF) receptor tyrosine kinase family, and the AR may be a determinant of tumour progression. Experiments with non-castrated and castrated mice inoculated with LNCaP cells overexpressing HER-2/neu showed that this oncogene can substitute for androgen and cause tumour growth in vivo.

In this study, we sought to clarify the relevance of AR activation by IL-6 for tumour growth in vitro and in vivo. The androgen-sensitive MDA PCa $2 \mathrm{~b}$ prostate cancer cell line expresses mutated (L701H and T877A) $\mathrm{AR}$ and is derived from a single bone metastasis from a patient with a relapsed tumour (Navone et al. 1997). MDA PCa $2 b$ cells were applied in our studies and stimulatory effect of IL-6 on their proliferation is shown for the first time. To better characterize the responsiveness to IL-6, the androgen-dependent
LAPC-4 prostate cancer cell line derived from a lymph node metastasis that expresses wild-type AR was examined as well (Klein et al. 1997).

\section{Materials and methods}

\section{Reagents}

The synthetic androgen methyltrienolone (R1881) was purchased from R\&D Systems (Minneapolis, MN, USA) and dissolved in absolute ethanol. Human recombinant IL-6 was provided by R\&D Systems and the working solution was prepared in PBS. Bicalutamide was a kind gift from Astra Zeneca (Macclesfield, UK). PD98059 was purchased from VWR (Vienna, Austria). Stock solutions of bicalutamide and PD98059 were prepared in dimethyl sulfoxide (DMSO). 5-azacytidine was obtained from Sigma and dissolved in acetic acid:water $(1: 1 \mathrm{v} / \mathrm{v})$.

\section{Cell culture}

The LAPC-4 prostate cancer cell line was a kind gift from Prof. Charles Sawyers (formerly at University of California, Los Angeles, CA, USA). The cells were cultured in Iscove's modified Dulbecco's (IMDM) medium (PAA Laboratories, Pasching, Austria) containing 15\% FCS (Szabo Scandic, Vienna, Austria), $100 \mathrm{U} / \mathrm{ml}$ penicillin, $100 \mathrm{U} / \mathrm{ml}$ streptomycin solution and $10 \mathrm{nM}$ R1881.

The MDA PCa $2 b$ prostate cancer cell line was obtained from Szabo Scandic. The cells were grown in F12 medium (Sigma-Aldrich) supplemented with $20 \%$ FCS, $100 \mathrm{U} / \mathrm{ml}$ penicillin, $100 \mathrm{U} / \mathrm{ml}$ streptomycin solution, $25 \mathrm{ng} / \mathrm{ml}$ cholera toxin (Sigma-Aldrich), $10 \mathrm{ng} / \mathrm{ml}$ EGF (Strathmann Biotech, Hannover, Germany), $5 \mu \mathrm{M}$ phosphoethanolamine, $100 \mathrm{pg} / \mathrm{ml}$ hydrocortisol and insulin/transferin/selenid mix (Invitrogen).

To investigate the responsiveness of prostate cancer cells to IL-6 after prolonged exposure to the cytokine, LAPC-4 and MDA PCa $2 b$ were maintained under regular culture conditions in the presence of $5 \mathrm{ng} / \mathrm{ml}$ IL-6 during a period of 3 weeks. After this period, new sublines named LAPC-4-IL-6 and MDA PCa 2b-IL-6 were generated and used in proliferation assays.

The AR negative CV-1 cell line derived from monkey kidney was obtained from ATCC (Rockville, MD, USA). CV-1 cells were cultured in DMEM (PAA Laboratories) supplemented with $10 \%$ FCS, $100 \mathrm{U} / \mathrm{ml}$ penicillin and $100 \mathrm{U} / \mathrm{ml}$ streptomycin. All cell lines were maintained at $37{ }^{\circ} \mathrm{C}$ in a humified $5 \% \quad \mathrm{CO}_{2}$ atmosphere. 


\section{${ }^{3} \mathrm{H}$-Thymidine uptake assay}

LAPC-4, LAPC-4-IL-6, MDA PCa 2b and MDA PCa $2 \mathrm{~b}$-IL-6 cells were seeded at a density of $10^{4}$ cells/well onto 96-well plates in regular culture media. Serum requirements for optimal growth were determined for each cell line and subline. The next day, media were changed and the cells cultured either without (MDA PCA 2b IL-6) or with 5\% steroid-free FCS (LAPC-4, LAPC-4-IL-6, MDA PCa 2b), $100 \mathrm{U} / \mathrm{ml}$ penicillin and $100 \mathrm{U} / \mathrm{ml}$ streptomycin. Cells were incubated with increasing doses of IL-6 $(1-50 \mathrm{ng} / \mathrm{ml})$. After incubation, the mix of $1 \mu \mathrm{l}^{3} \mathrm{H}$-thymidine $(1 \mu \mathrm{Ci} /$ well $)$ and $49 \mu \mathrm{l}$ serum-free medium/well was added. Cells were then harvested after $24 \mathrm{~h}$ and DNA was fixed on filter plates (UniFilter, Perkin Elmer, Boston, MA, USA). Chameleon 5025 liquid scintillation counter (HVD Life Sciences, Vienna, Austria) was used to read the filter plates.

\section{Cell counting}

MDA PCa $2 b$ cells were seeded at a density of $5 \times 10^{5}$ cells/well onto six-well plates in regular culture medium. They were incubated with IL-6 $(25 \mathrm{ng} / \mathrm{ml})$, bicalutamide $(5 \mu \mathrm{M})$ or PD98059 $(25 \mu \mathrm{M})$ for $72 \mathrm{~h}$. The cells were trypsinized, centrifuged and cell pellet was suspended in $1 \mathrm{ml}$ PBS. $100 \mu \mathrm{l}$ cell suspension in PBS was added to $10 \mathrm{ml}$ Casy Ton buffer (Innovatis, Reutlingen, Germany). The cell number based on the cell size was counted by the instrument (Schaerfe System, Reutlingen, Germany).

\section{Reverse transcription PCR}

LAPC-4 and MDA PCa $2 b$ cells were incubated for $48 \mathrm{~h}$ in the absence or presence of the demethylating agent 5-azacytidine $(1-5 \mu \mathrm{M})$. RNA was isolated according to the manufacturer's instructions (Qiagen). The procedure of cDNA reverse transcription with Super Script III RT (Invitrogen) was based on the manufacturer's protocol. The IL-6 gene fragment was amplified by PCR with the primers: sense, $5^{\prime}$-CCT CCAGAACAGATTTGAGA- $3^{\prime}$; antisense, 5'-CCT TAAAGCTGCGCAGAATG- $3^{\prime}$ under the following conditions: $2 \mathrm{~min}$ at $94{ }^{\circ} \mathrm{C}, 30$ cycles of $50 \mathrm{~s}$ at $95^{\circ} \mathrm{C}$, $1 \mathrm{~min}$ at $56^{\circ} \mathrm{C}, 15 \mathrm{~s}$ at $73{ }^{\circ} \mathrm{C}$, with the final extension time of $3 \mathrm{~min}$ at $73{ }^{\circ} \mathrm{C}$. The gp 80 gene fragment was amplified with the primers: sense, $5^{\prime}$-TCGCCAGTA GTGTCGGGAGCA-3'; antisense, 5'-GCCTTCCTT CAGAGCCCGCAG- $3^{\prime}$ and the gp130 gene fragment was amplified with the primers: sense, $5^{\prime}$-CCACAT ACGAAGACAGACCA-3'; antisense, 5'-GCGTTC TCTGACAACACACA- $3^{\prime}$ under the following conditions: $15 \mathrm{~min}$ at $95{ }^{\circ} \mathrm{C}, 35$ cycles of $50 \mathrm{~s}$ at $95^{\circ} \mathrm{C}, 1 \mathrm{~min}$ at $60{ }^{\circ} \mathrm{C}, 40 \mathrm{~s}$ at $73{ }^{\circ} \mathrm{C}$, with the final extension time of $3 \mathrm{~min}$ at $73{ }^{\circ} \mathrm{C}$. The fragments were visualized using $2 \%$ agarose gel electrophoresis.

\section{IL-6 ELISA}

MDA PCa $2 b$ and LAPC- 4 cells were seeded onto sixwell plates at a density of $2.5 \times 10^{5}$ cells/well in regular culture media and let to attach and reach the subconfluence. The cells were treated with TNF $\alpha$ $(1-5 \mathrm{ng} / \mathrm{ml})$ or IL-1 $\beta(0.1-0.5 \mathrm{ng} / \mathrm{ml})$ for $72 \mathrm{~h}$. After the incubation period, the supernatant from the cells was collected and used for further investigations. Cells were harvested by trypsinization and counted by Casy cell counter. Human IL-6 ELISA (Bender System, Vienna, Austria) assay was performed according to the manufacturer's instructions. The results of the assay were normalized according to the cell number.

\section{Western blot analysis}

LAPC-4 and MDA PCa 2 b cells were seeded in culture media and let to grow to subconfluence. After $24 \mathrm{~h}$ incubation, the cells were maintained in fresh serumfree medium. Cells were incubated with increasing concentrations of IL- 6 between 5 and 45 min and then harvested and lyzed with European Organization for Research and Treatment of Cancer (EORTC) lysis buffer by incubation on ice for $20 \mathrm{~min}$. The lyzed cells were centrifuged 13000 r.p.m. for $10 \mathrm{~min}$ and the supernatant (cytosolic fraction) was collected. The amount of protein was measured by Bradford method (Bradford 1978) and 20-50 $\mu \mathrm{g}$ protein were used for SDS-PAGE analysis. Polyacrylamide $4-12 \%$ gradient Bis-Tris gel (Invitrogen) was run in $1 \times$ MOPS (Invitrogen) buffer at $150 \mathrm{~V}$. Transfer of the proteins to PVDF membrane (Invitrogen) was done in $1 \times$ transfer buffer (Invitrogen) containing 10\% methanol at $30 \mathrm{~V}$ for $1 \mathrm{~h}$. Membrane was blocked in Starting Block buffer (Pierce Biotechnology, Rockford, IL, USA) for $1 \mathrm{~h}$ at room temperature and then incubated with either phospho-specific p44/p42 MAP kinase (Thr 202/Tyr 204) E10 mouse monoclonal antibody (New England Biolabs, Beverly, MA, USA), p44/p42 rabbit polyclonal antibody (Santa Cruz Biotechnology, Santa Cruz, CA, USA), phospho-specific STAT3 (Y 705, clone 9E12) mouse monoclonal antibody (Cell Signalling, Danvers, MA, USA), STAT3 (C-20) rabbit polyclonal antibody (Szabo Scandic), Jak1 (413104) rat monoclonal antibody (R\&D Systems), Jak2 (691R5) mouse monoclonal antibody (Abcam, Cambridge, UK), phospho-specific Akt (Ser 473) rabbit polyclonal antibody (Cell Signalling) or Akt 
(C-20) goat polyclonal antibody (Santa Cruz) overnight. The fluorescent signals were read using the Odyssey infrared imaging system (LiCor Biosciences, Lincoln, NE, USA).

\section{Transfections}

CV-1 cells were seeded onto 24-well plates at a density of $10^{5}$ cells/well in regular culture medium. After $24 \mathrm{~h}$ the medium was changed and transfection with Fugene 6 (Roche) was performed in serum-free conditions according to the manufacturer's instructions. Cells were transiently transfected with the reporter construct ARE $_{2}$-TATA-luc (pGL3-E) and either wild-type (pSG5-AR) or mutated (L701H and T877A) AR expression vector $\left(\mathrm{pSG} 5-\mathrm{AR}_{\mathrm{L} 701 \mathrm{H}, \mathrm{T} 877 \mathrm{~A}}\right.$ was a kind gift from Prof. David Feldman, Stanford University School of Medicine, Stanford, CA, USA). We used 400 ng DNA per well with the ratio between reporter gene and AR of 20:1. The plasmid pGL4.73 encoding renilla gene $(30 \mathrm{ng})$ was used as a transfection efficiency control.

\section{In vivo experiments}

Three to four weeks old male nude mice ( $n u / n u$ $\mathrm{BALB} / \mathrm{c}$ ) were purchased from Charles River Laboratories (Sulzfeld, Germany) and allowed to acclimate for 1 week. All procedures involving mice were approved by Austrian Federal Ministry of Science and Research (GZ BMWF-66.011/0076-C/GT/2007). MDA PCa 2b cells suspended in $50 \mu 1 \mathrm{PBS}$ and mixed with the same volume of Matrigel (BD Biosciences, Two Oak Park, Bedford, MA, USA) were injected subcutaneously into the right flank of all mice $\left(n=10 ; 6 \times 10^{6}\right.$ cells per mouse; Fig. 1). Tumour size was measured using a calliper and tumour volume was calculated according to the formula: length $\times$ width $^{2}$ of a tumour area/2. The tumours were harvested after they reached the mean volume of $1200 \mathrm{~mm}^{3}$ and passed from mouse to mouse. A new group of mice $(n=22)$ was inoculated with tumour tissues $\left(300 \mathrm{~mm}^{3}\right.$ per mouse). After tumours reached the mean volume of $400 \mathrm{~mm}^{3}$, mice were grouped as follows: 1) non-castrated $(n=8), 2)$ castrated and treated with IL-6 $(n=8), 3)$ castrated and treated with IL- 6 and bicalutamide $(n=6)$. Orchiectomy was performed under anaesthesia using ketamine- $\mathrm{HCl}$ and xylazine- $\mathrm{HCl}(100 \mathrm{mg} / \mathrm{kg}$ mouse i.p. and $10 \mathrm{mg} / \mathrm{kg}$ mouse i.p. respectively). To inhibit an inflammatory response, $4 \mathrm{mg} / \mathrm{kg}$ mouse of ketoprofen s.c. during the first day after castration was used. Treatment with $200 \mathrm{ng}$ IL-6 i.p. twice per day and $50 \mathrm{mg} / \mathrm{kg}$ mouse of bicalutamide i.p. twice per week was initiated immediately (Culig et al. 1999,

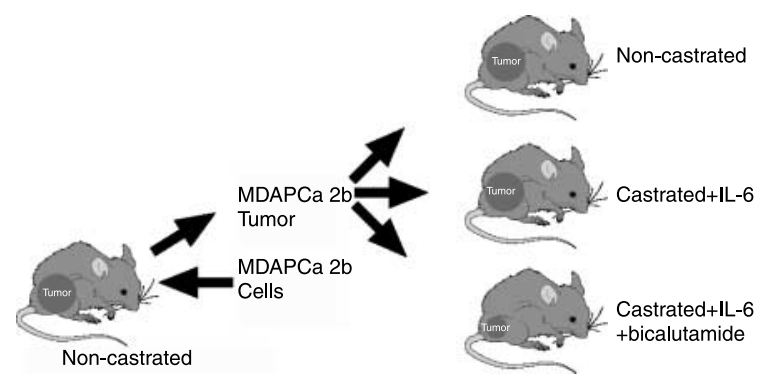

Figure 1 Schematic overview of in vivo experiments.

Wang et al. 2004). General condition of animals allowed performance of experiments until day 38 . The mice were killed by cervical dislocation.

\section{Statistical analysis}

The SPSS 12.0 program was used for statistic evaluation and the Mann-Whitney $U$-test was used for the assessment of statistical significance.

ANOVA test was applied to evaluate statistical significance of the tumours' volume between noncastrated versus IL-6-treated mice and IL-6-treated mice versus IL-6 and bicalutamide-treated mice.

\section{Results}

\section{Proliferative response of LAPC-4 and MDA PCa $2 b$ cells to IL- 6 treatment}

In order to characterize the interactions between IL-6 and the AR, we initially studied the growth response of two AR-positive cell lines to IL-6 treatment. We observed a dose-dependent significant growth inhibition of LAPC-4 cells after 48 h (Fig. 2A), an effect similar to that previously reported in parental LNCaP cells (Degeorges et al. 1996, Mori et al. 1999). In MDA PCa $2 b$ cells, increasing doses of IL-6 enhanced proliferation (Figs 2B and 3). We have further examined whether the inhibition of AR activity by the anti-androgen bicalutamide has an effect on IL-6induced proliferation of MDA PCa $2 \mathrm{~b}$ cells. The proliferation of MDA PCa $2 b$ cells was inhibited in the presence of IL- 6 and bicalutamide compared with IL-6 treatment alone. PD98059, an inhibitor of the MAP kinase pathway, abolished the effect of IL- 6 on growth stimulation (Fig. 3).

To verify whether long term treatment with IL-6 has opposite effects on cell proliferation to transient treatment, we established new sublines of LAPC-4 and MDA PCa 2b cells, named LAPC-4-IL-6 and MDA PCa 2b-IL-6. Continuous exposure of LAPC-4 cells to IL-6 did not alter the pattern of the response to 

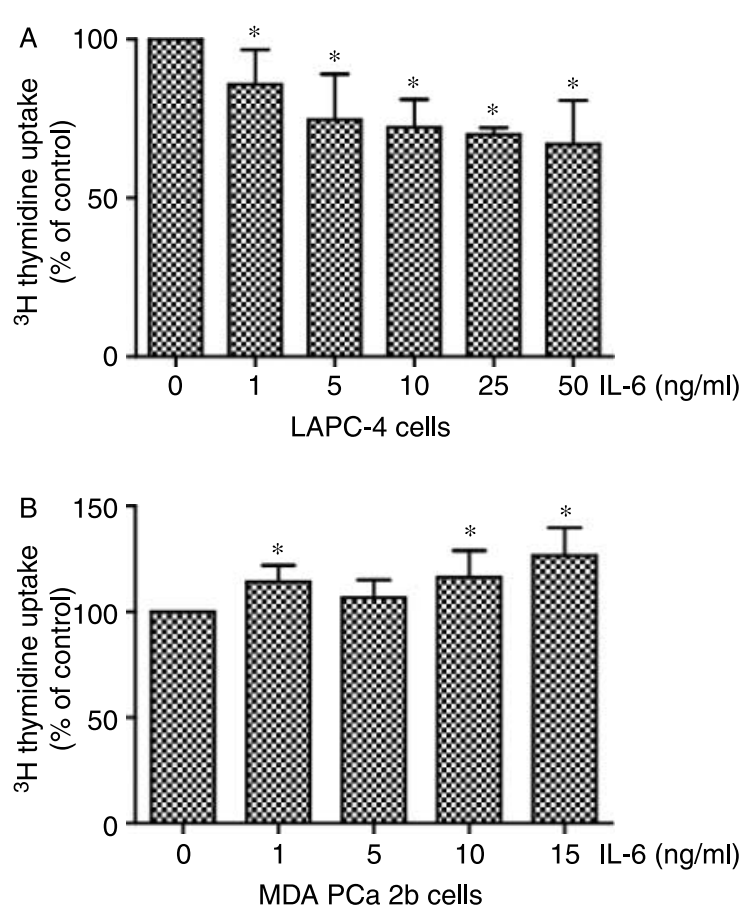

Figure $2{ }^{3} \mathrm{H}$-thymidine incorporation assay after treatment with increasing doses of IL-6 for $48 \mathrm{~h}$ in (A) LAPC-4 and (B) MDA $\mathrm{PCa} 2 \mathrm{~b}$ cells. Data represent the mean \pm s.D. $n=3$. ${ }^{*} P<0.05$ versus control, Mann-Whitney $U$-test.

increasing doses of IL-6 and inhibition of proliferation was still observed (Fig. 4A). Basal proliferation rate of the LAPC-4-IL-6 subline was similar to that of the parental LAPC-4. Interestingly, in the MDA PCa 2b-IL6 subline a significant increase in proliferation was achieved with higher doses of IL-6 (25 and $40 \mathrm{ng} / \mathrm{ml})$ than in parental MDA PCa 2b cells (Figs 2B and 4B). Long term treatment of MDA PCa $2 b$ cells with IL-6 markedly enhanced basal proliferation in comparison to the parental cell line. Additionally, we did not

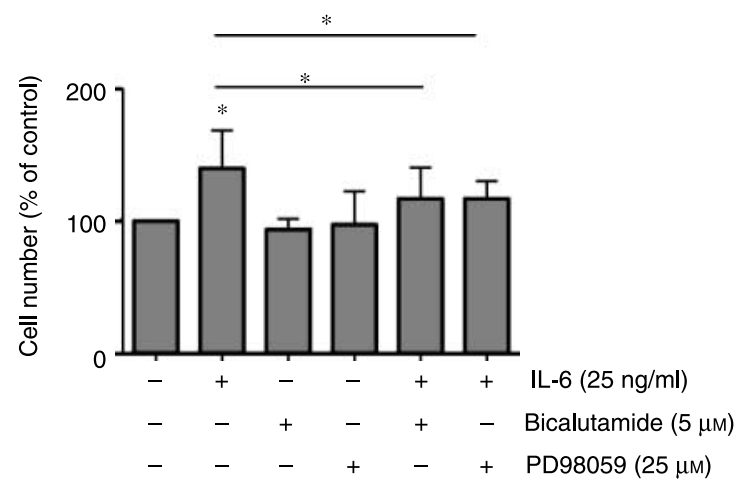

Figure 3 Effects of bicalutamide or PD98059 in the presence of IL-6 in MDA PCa $2 b$ cells. Data represent the mean \pm s.D. $n=3$. ${ }^{\star} P<0.05$ versus control, Mann-Whitney $U$-test. observe apparent changes in morphology and phenotype of LAPC-4-IL-6 and MDA PCa 2b-IL-6 sublines by phase contrast microscopy (data not shown).

\section{Expression of IL- 6 and IL-6R in LAPC-4 and MDA PCa $2 b$ cells}

In this set of experiments, we examined if IL-6 affects LAPC-4 and MDA PCa $2 b$ cells proliferation in a paracrine or autocrine fashion. To investigate this issue, RT-PCR and ELISA for IL- 6 were perfomed. In contrast to IL-6-positive PC-3 cells, IL-6 mRNA was not detected in either LAPC-4 or MDA PCa $2 b$ cell line growing under basal conditions (Fig. 5). Promoter hypermethylation was considered as a possible mechanism involved in IL-6 gene suppression. However, a $48 \mathrm{~h}$ treatment of cells with the demethylating agent 5-azacytidine did not induce the expression of the cytokine (Fig. 5). To confirm the absence of IL-6 secretion, conditioned media from LAPC-4 and MDA PCa $2 \mathrm{~b}$ cells were subjected to ELISA. IL- 6 was not secreted by either untreated cells or those treated with TNF . $\alpha$ or IL-1 $\beta$, known to act as inducers of expression of the IL-6 gene (data not shown; Kohase et al. 1986, Kitamura et al. 1998).

On target cells, IL-6 acts via a receptor complex composed of a ligand-binding $80 \mathrm{kDa}$ glycoprotein (gp80, IL-6R) and a $130 \mathrm{kDa}$ signal-transducing receptor subunit (gp130). The investigated cell lines expressed both subunits of the receptor complex as detected by RT-PCR (Fig. 6). Taken together with the results of proliferation experiments, these data imply that IL-6 regulates growth of both cell lines in a paracrine manner.

\section{Lack of STAT3 phosphorylation in the LAPC-4 and MDA PCa $2 b$ cell lines after IL- 6 treatment}

The Jak-STAT pathway is one of the classical signalling pathways activated by IL- 6 that may be implicated in carcinogenesis in different ways. It has been shown that IL-6 induces transcriptional activity of STAT3 in parental LNCaP cells (Spiotto \& Chung 2000). To understand the role of STAT3 in IL-6regulated growth of LAPC-4 and MDA PCa $2 b$ cells, western blot analyses of phosphorylated and total STAT3 were performed. STAT3 protein was detected in both cell lines. We measured the levels of STAT3 phosphorylation at tyrosine residue 705 in cells treated with IL-6 at different time points after $24 \mathrm{~h}$ of serum starvation. As shown in Fig. 7, we did not observe a constitutive or IL-6-induced STAT3 phosphorylation in either cell line. In parental LNCaP cells that were used as a control, the addition of $10 \mathrm{ng} / \mathrm{ml}$ IL- 6 entailed 

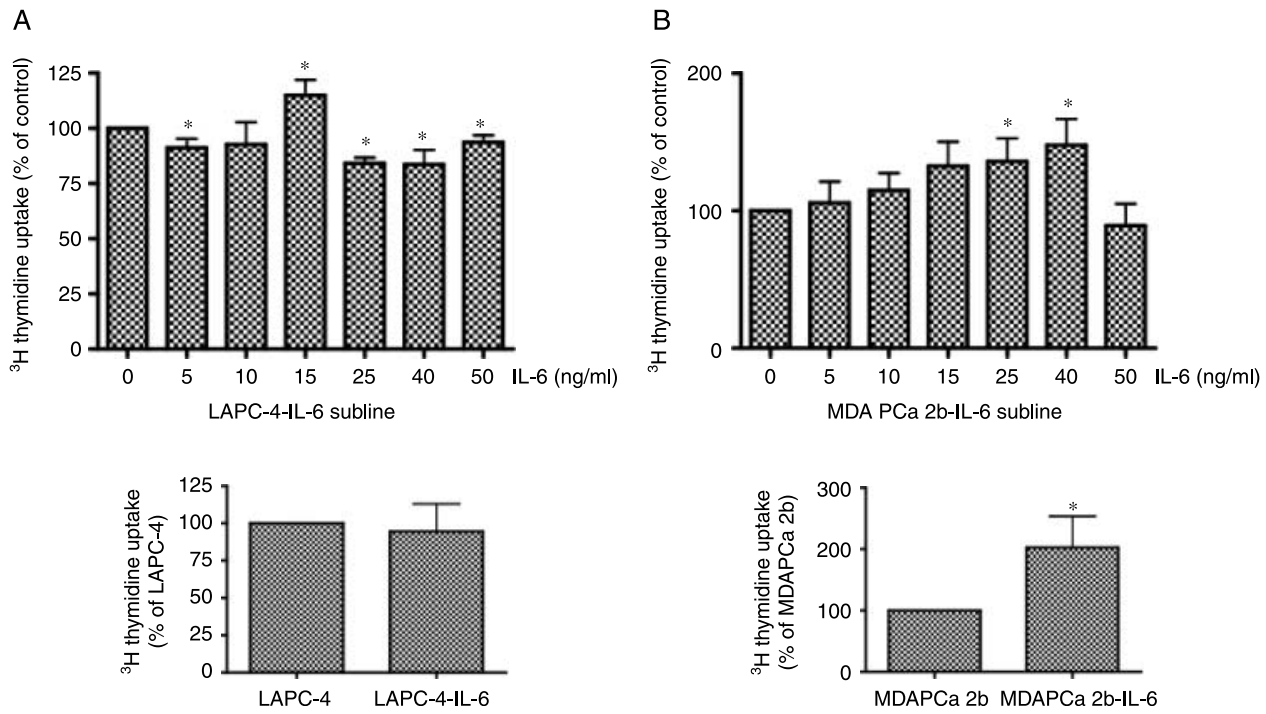

Figure 4 Regulation of growth of prostate cancer cell sublines established after long term treatment with IL-6. ${ }^{3} \mathrm{H}$-thymidine incorporation assay after treatment with increasing doses of IL-6 in (A) LAPC-4-IL-6 and (B) MDA PCa $2 b-I L-6$ sublines. Basal proliferation of (A, lower panel) LAPC-4-IL-6 and LAPC-4 set as 100\% and (B, lower panel) MDA PCA $2 b-$ IL-6 and MDA PCa $2 b$ set as $100 \%$ is shown. Data represent the mean \pm S.D. $n=3$. ${ }^{*} P<0.05$ versus control, Mann-Whitney $U$-test.

an increase in the phosphorylated form of STAT3 (Godoy-Tundidor et al. 2005). The lack of STAT3 phosphorylation raised a question about the expression of signalling intermediates such as Jak1 and Jak2. In both studied cell lines, constitutive expression of Jak1 was observed (Fig. 8A). Interestingly, Jak2 was detected in MDA PCa $2 b$ but not in LAPC-4 cells (Fig. 8B).

A

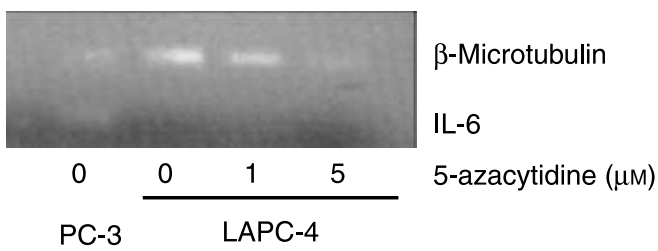

B

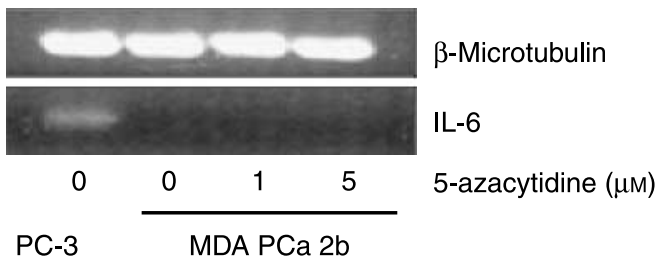

Figure 5 Analysis of expression of IL-6 in (A) LAPC-4 and (B) MDA PCa $2 b$ cells. IL- 6 mRNA was not detected by RT-PCR in cells growing under basal conditions or after treatment with the demethylating agent 5-azacytidine. PC-3 cells were used as a positive control.

\section{Phosphorylation of MAP kinases in LAPC-4 and MDA PCa $2 b$ cells following IL- 6 treatment}

Activation of p44/p42 MAP kinase after treatment with IL-6 is mostly associated with increased proliferation (Nakafuku et al. 1992, Daeipour et al. 1993). To further analyze IL-6 signal transduction pathways, we examined the effect of IL- 6 on p44/p42 phosphorylation. After $15 \mathrm{~min}$ of incubation, IL-6 $(10 \mathrm{ng} / \mathrm{ml})$ significantly elevated phosphorylation of $\mathrm{p} 42$ in MDA PCa $2 b$ cells (Fig. 9A). IL-6, at concentrations of 10 or $25 \mathrm{ng} / \mathrm{ml}$, increased the amount of the phosphorylated form of p44 (Fig. 9A). However, it should be mentioned that the basal levels of phosphorylated p44/p42 in the MDA PCa 2b cell line were elevated, comparable with those previously observed in androgen-insensitive cell lines (Putz et al. 1999). By contrast, we did not observe any phosphorylation of $\mathrm{p} 44 / \mathrm{p} 42$ in LAPC-4 cells in the absence or presence of IL-6 (Fig. 9B). The results correlated with those from proliferation assays, suggesting a role of the MAP kinase pathway in the growth stimulation of MDA PCa $2 \mathrm{~b}$ cells.

\section{Phosphorylation of Akt in the LAPC-4 and MDA PCa $2 b$ cell lines after IL- 6 treatment}

As established before, the PI3-K-Akt pathway may be activated after IL-6 treatment (Chen et al. 1999a). To test phosphoregulation of Akt by IL-6, LAPC-4 and MDA PCa $2 b$ cells were subjected to IL- 6 stimulation 
A

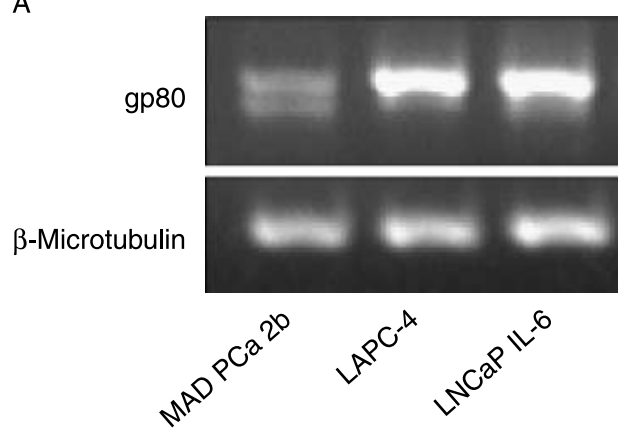

B

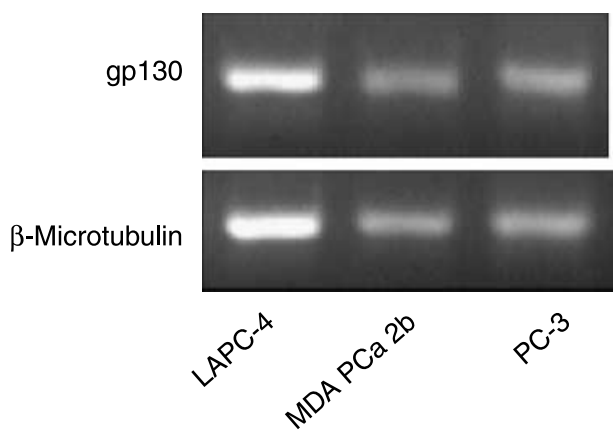

Figure 6 Analysis of expression of gp80 and gp130 in prostate cancer cells by RT-PCR. LNCaP-IL-6- and PC-3 cells were used as positive controls respectively.

with doses up to $25 \mathrm{ng} / \mathrm{ml}$ at several time points. Interestingly, $25 \mathrm{ng} / \mathrm{ml}$ IL-6 induced a significant upregulation of phosphorylated Akt in LAPC-4 cells after $15 \mathrm{~min}$ (Fig. 10A). Western blot analysis revealed the lack of the activated form of Akt in MDA PCa $2 b$ cells under basal culture conditions and after treatment with IL-6 (Fig. 10B).

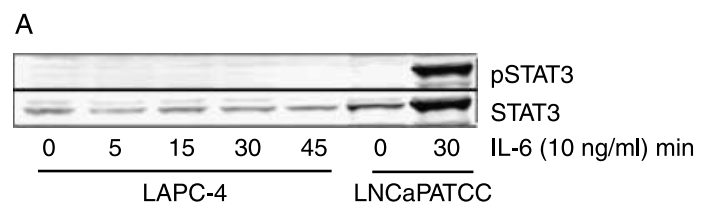

B

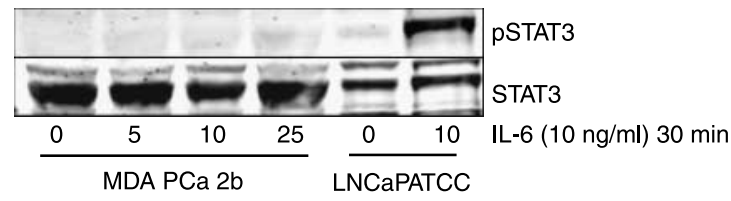

Figure 7 Lack of STAT3 phosphorylation in prostate cancer cells LAPC-4 and MDA PCa $2 b$. After treatment of (A) LAPC-4 and (B) MDA PCa $2 b$ cells with IL-6, we did not observe phosphorylation of STAT3 in contrast to LNCaP ATCC cells in which IL-6 caused an increase in phoshorylated STAT3.
A

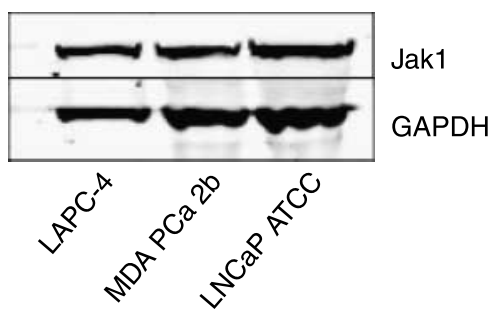

B
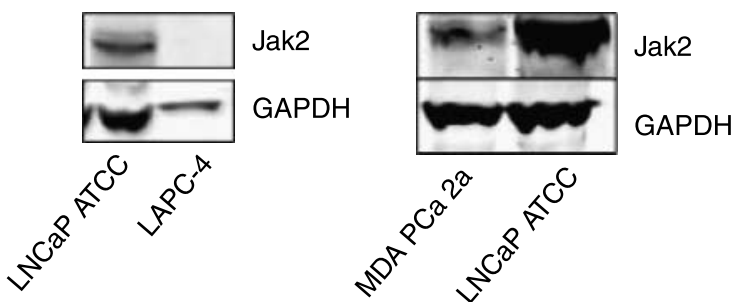

Figure 8 Expression of Jak1 and Jak2 in prostate cancer cells. (A) Jak1 expression was detected in both cell lines. (B) The lack of Jak2 was observed in LAPC-4 in contrast to MDA PCa $2 b$ cells. LNCaP ATCC cells were used as positive controls.

\section{Activation of wild-type and mutated AR}

Since the MDA PCa $2 b$ cell line is in our experimental conditions, the only AR-positive cell line that responds to IL-6 treatment by growth stimulation, we have selected those cells for the in vivo experiment. Prior to initiation of the in vivo study, we verified whether IL-6 activates the mutated AR. To compare activation potency between the wild-type $A R$ and the $A R$ carrying the double mutations (L701H and T877A), we used CV-1 cells in which either receptor and androgen-responsive reporter were transiently expressed. Cells cotransfected with the wild-type AR showed a high induction of reporter gene expression by androgen (13.9-fold; Fig. 11A). In comparison with the wild-type AR, a reduced effect on expression of luciferase gene was noted for the mutated form of AR (Fig. 11B). These findings are in accordance with the report of Zhao et al. (1999). The action of androgen was diminished by bicalutamide in cells with either wild-type (Fig. 11A) or mutated AR (Fig. 11B). Bicalutamide itself exerted a partial stimulatory effect on AR activity, consistent with results reported by others (Hara et al. 2003). In our experimental system, IL-6 was able to slightly increase the expression of reporter gene in the presence of mutated AR (Fig. 12).

\section{The role of IL-6 in tumour progression in vivo}

On the basis of our proliferation assays with MDA PCa $2 \mathrm{~b}$ cells, we hypothesized that IL- 6 is able to induce 
A
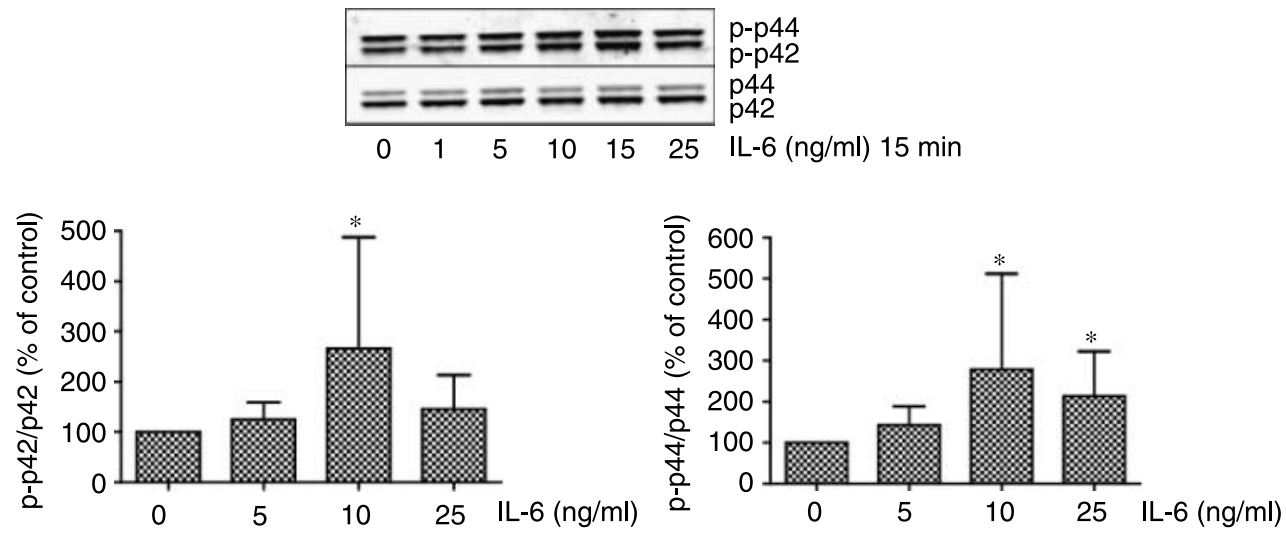

B

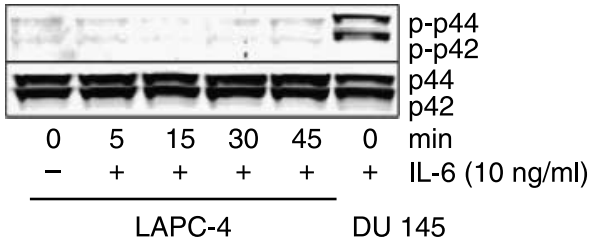

Figure 9 Effect of IL-6 on activation of the MAP kinase pathway. IL-6 significantly increased MAP kinase phosphorylation in (A) MDA $\mathrm{PCa} 2 \mathrm{~b}$ cells in which the basal levels of phosphorylated $\mathrm{p} 44 / \mathrm{p} 42$ are elevated. Data represent the mean \pm s.D. $n=3$. ${ }^{\star} P<0.05$ versus control, Mann-Whitney U-test. (B) IL-6 does not affect p44/p42 phosphorylation in LAPC-4 cells. DU-145 cells were used as a positive control.

tumour growth in vivo. To address the main question of the present study, i.e. whether IL-6 promotes prostate tumour growth through AR activation, MDA PCa $2 b$ cells were xenografted into nude mice. To obtain the tumourigenic MDA PCa $2 \mathrm{~b}$ cells, we passed them on non-castrated $n u / n u$ immune-deficient mice. After 10 weeks, we observed tumour growth and used those tumour tissues for inoculation in another group of $n u / n u$ immune-deficient mice. In the non-castrated animals, the tumour volume reached $1119 \mathrm{~mm}^{3}$ after 5.5 weeks (Fig. 13), whereas in castrated animals that received daily IL- 6 treatment, the mean tumour volume was found to be $990 \mathrm{~mm}^{3}$ at the end of the experiment (Fig. 13). By contrast, tumours did not significantly grow in castrated IL-6 and bicalutamidetreated mice (Fig. 13). These results showed that the action of IL-6 is antagonized by bicalutamide in vivo thus providing new insights about the significance of interactions between IL- 6 and the AR in regulation of prostate cancer growth (Figs 1 and 13).

\section{Discussion}

It has been hypothesized that ligand-independent activation of the AR is one of the mechanisms implicated in prostate tumour progression. So far most of the studies have reported the results on AR regulation by a number of non-steroidal compounds. In those studies, transactivation assays in heterologous cell lines were performed. However, little is known about specific cellular events that are regulated by interactions between most activators of the AR and the receptor itself. IL-6 is a multifunctional cytokine that enhances AR activity in the absence of ligand and is increasingly expressed in prostate cancer tissue in early stages. IL-6 levels higher than $7 \mathrm{pg} / \mathrm{ml}$ correlate with bad prognosis (Nakashima et al. 2000). Prostatic tumours typically metastasize to bone, lymph nodes and liver, organs in which IL-6 is present. For these reasons, investigations on regulation of growth of androgen-dependent xenografts by IL-6 may be of high clinical relevance.

The key finding of our study is that, IL-6 similarly to HER-2/neu can substitute for androgen in stimulation of AR-positive tumour growth in vivo. It is, however, not clear to which extent the implications of our results could be generalized. We selected MDA PCa $2 b$ cells for the in vivo study since two other AR-positive cell lines, LNCaP or LAPC-4 is growth-inhibited in vitro, as evidenced in the present and previous publications 


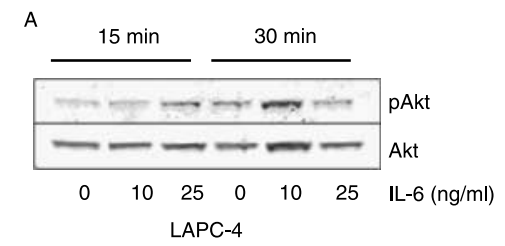

B
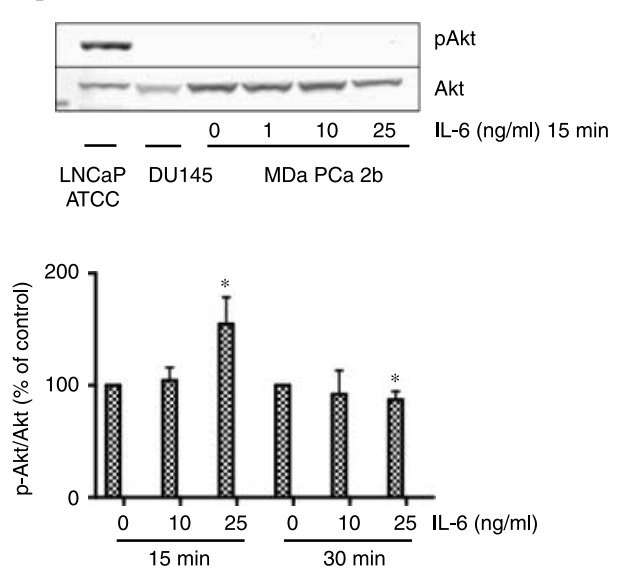

Figure 10 (A) Treatment of LAPC-4 cells with $25 \mathrm{ng} / \mathrm{ml} \mathrm{IL-6}$ caused an increase of the phosphorylated form of Akt. (B) By contrast, no phosphorylation of Akt in MDA PCa $2 b$ cells was observed. Data represent the mean \pm s.D. $n=3$. ${ }^{\star} P<0.05$ versus control, Mann-Whitney U-test. LNCaP ATCC and DU145 cells were used as positive or negative controls, respectively.

(Hobisch et al. 2001). Moreover, in vivo growth of LNCaP cells was suppressed by IL-6 as published by Wang et al. (2004). It should be, however, mentioned that contrasting effects of IL-6 in LNCaP cells in vitro were reported. These variances may be explained by recent findings according to which phosphorylation of STAT3 is dependent on cell density in melanoma (Kreis et al. 2007). If this phenomenon is also relevant to prostate cancer models, one could better understand why divergent results on growth regulation and STAT3 phosphorylation were obtained with LNCaP cells. The role of STAT3 in development and progression of several malignancies has been well-documented (Horiguchi et al. 2002). Although, there are many examples demonstrating that STAT3 exerts oncogenic features, its action as an inhibitor of tumour growth has also been reported (Moran et al. 2008). One emerging concept supported by our own data is that the anti- or proapoptotic role of STAT3 is determined by the presence of suppressor of cytokine signalling-3 (SOCS-3). SOCS-3 expression was not induced by IL-6 in cells in which phosphorylation of STAT3 is associated with growth retardation and differentiation (Bellezza et al. 2006). Interestingly, we reported the lack of pSTAT3 in LAPC- 4 or MDA PCa $2 b$ cell lines under basal conditions and after IL- 6 incubation. Signalling of IL-6 involves intermediate molecules like Jak1 or Jak2. Both LAPC-4 and MDA PCa 2 b cells express Jak1, whereas Jak2 is present only in MDA $\mathrm{PCa} 2 \mathrm{~b}$ cells. On the basis of studies performed in other cell lines, diverse mechanisms could be considered for explanation of lack of phosphorylation of STAT3. In a number of plasma cell lines, STAT3 phosphorylation in response to IL- 6 was detected although Jak1 protein is not expressed (Kopantzev et al. 2002). Those authors also demonstrated that IL-6 may fail to induce phosphorylation of Jak2 in plasma cells. Finally, STAT3 phosphorylation might be influenced by the MAP kinase pathway in different ways. Studies performed with the herbal remedy magnolol in endothelial cells support the view that Jak-independent mechanisms also regulate STAT3 phosphorylation (Chen et al. 2006). Magnolol suppressed IL-6 effect on STAT3 phosphorylation without causing an inhibition of Jak activation.

Diverse growth factors, cytokines and protooncogene products activate the small $G$ protein Ras and subsequently the MAP kinase network (Papatsoris et al. 2007). MAP kinase is also a classical pathway for IL-6 and its activation is frequently associated with either reduced apoptosis or, more commonly, enhanced proliferation (Culig et al. 2005a). Ras and Raf mutations are not frequent in prostate cancer (Dong 2006) and it could be hypothesized that wild-type Ras and/or Raf are activated by growth factors in an autocrine and paracrine manner during prostate carcinogenesis. It has been suggested that activation of Ras through the MAP kinase pathways modulates AR-dependent gene expression (Bakin et al. 2003). Previous studies revealed that AR function is influenced by Ras/MAP kinase interactions with AR-associated proteins (Culig et al. 2005b). Elevation of PSA levels is also a p44/p42-sensitive phenomenon in androgen-independent conditions (Franco et al. 2003). MDA PCa 2b cells after incubation with IL-6 showed an increase in phosphorylation of p44/p42 kinases. Steiner et al. (2003) reported that the functional MAP kinase pathway is at least partly responsible for enhanced growth of cells generated after long term IL-6 treatment. MDA PCa $2 b$ is another example of a cell line in which IL-6-induced MAP kinase activity is associated with growth stimulation. In parental LNCaP cells whose growth is inhibited by IL-6, there is no constitutive MAP kinase activity (Chen et al. 1999b, Putz et al. 1999). We did not observe phosphorylation of $\mathrm{p} 44 / \mathrm{p} 42$ in LAPC-4 cells that respond to IL-6 exposure by inhibition of 

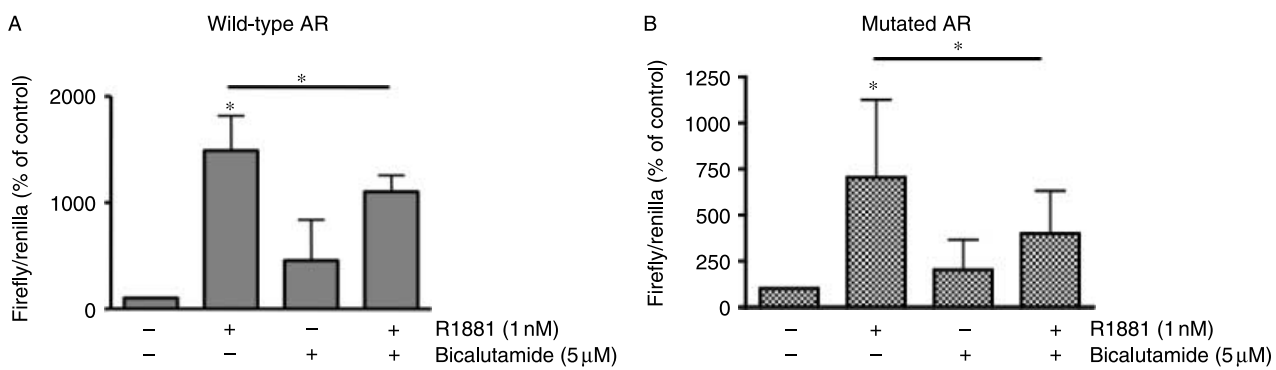

Figure 11 Transcriptional activity of either (A) wild-type or (B) MDA PCa $2 b$ mutated AR after treatment with the synthetic androgen methyltrienolone (R1881). The effects of androgen were blocked by the anti-androgen bicalutamide. Data represent the mean \pm S.D. $n=4$ (wild-type AR), $n=5$ (mutated AR). ${ }^{*} P<0.05$ versus control, Mann-Whitney $U$-test.

proliferation. All these observations implicate that there is an activation of the MAP kinase pathway in cell lines whose proliferation is increased by IL-6. A similar effect on MAP kinase phosphorylation was found with IL-8, a cytokine that also causes AR activation. Its modest effect on proliferation of $\mathrm{LNCaP}$ cells was demonstrated by Seaton et al. (2008).

IL-6 treatment can cause activation of the PI3-K-Akt pathway in prostate cancer cells. Yang et al. (2003) demonstrated suppression of AR activity by IL-6 via the PI3-K-Akt. Functional significance of IL-6-induced Akt phosphorylation in LAPC-4 cells could not be explained in the present study. One could expect that activation of that pathway will decrease apoptosis. In this particular case, a possibility that pAkt action on downstream genes is antagonized by endogenous Akt inhibitors may be considered.

Following chronic treatment with IL-6, prostate cancer cells can alter the responsiveness to the cytokine. $\mathrm{LNCaP}$ cells acquired the ability to proliferate at a higher rate and become more tumourigenic (Hobisch et al. 2001, Steiner et al. 2003). Our novel sublines were generated after the time period of 3 weeks, similarly to the approach by Sortino et al. (2000) who exposed prostate cancer cells to the nerve

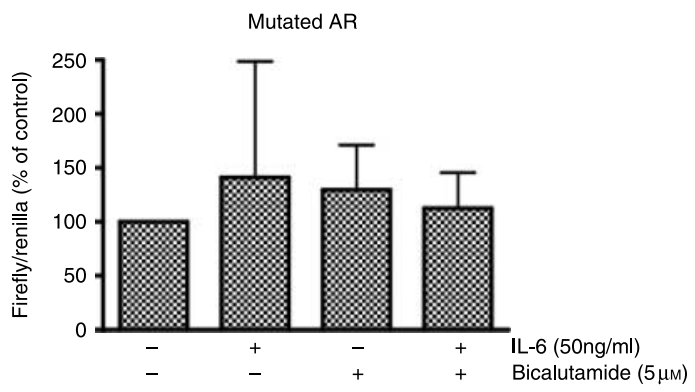

Figure 12 IL-6 effect on activation of the mutated AR. Luciferase assays were performed in CV-1 cells cotransfected with reporter gene and mutated AR expression vector after treatment with IL-6. growth factor treatment for 2 weeks. The new subline MDA PCa 2b-IL-6 acquired a growth advantage after IL-6 exposure in contrast to LAPC-4-IL-6 cells, thus suggesting that the regulation previously observed in a LNCaP subline may be of general relevance (Hobisch et al. 2001).

IL-6 significantly induced the growth of MDA PCa $2 \mathrm{~b}$ xenografts in nude mice. The stimulation of tumour formation by IL-6 appears to be a result of AR activation by IL- 6 signalling because the non-steroidal anti-androgen bicalutamide antagonizes this effect. It should be kept in mind that there is a clear ligandindependent pro-differentiation effect of IL-6 on expression of the AR-target gene PSA in LNCaP cells (Ueda et al. 2002a). Two recent publications have also addressed the issue of biological significance of non-steroidal AR activation in prostate disease. Importantly, Wang et al. (2006) demonstrated that expression of only a limited number of genes is targeted by cross-talk between androgen and the protein kinase A (PKA) pathway. On the basis of reporter gene studies, one could expect a higher

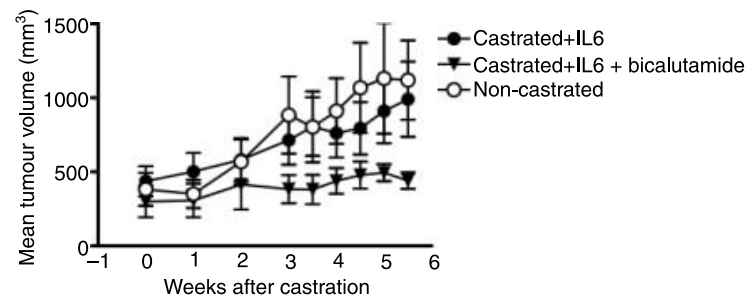

Figure 13 Growth of MDA PCa $2 b$ tumours in male nude $n u / n u$ immune-deficient mice. MDA PCa $2 \mathrm{~b}$ cells were injected into non-castrated or castrated male nude mice. Castrated animals were treated with IL- 6 or IL- 6 and bicalutamide. Tumour size was measured once weekly. Data represent the mean \pm s.D. $n=8$ (non-castrated), $n=8$ (castrated +IL-6-treated), $n=6$ (castrated + IL-6+ bicalutamide-treated). Significance between the animals' groups was calculated with ANOVA $(P<0.001$, IL- 6 treatment versus IL- 6 and bicalutamide treatment; $P<0.01$, control versus IL-6 and bicalutamide treatment). 
Table 1 Responsiveness of androgen receptor (AR)-positive prostate cancer cells to interleukin-6 (IL-6) and activation of signalling pathways

\begin{tabular}{|c|c|c|c|}
\hline & LAPC-4 & LNCaP & MDA PCa 2b \\
\hline IL-6 effect on proliferation & Inhibition & Inhibition & Stimulation \\
\hline Androgen dependency & Dependent & Independent & Independent \\
\hline Androgen sensitivity & Sensitive & Sensitive & Sensitive \\
\hline \multicolumn{4}{|l|}{$\begin{array}{l}\text { Activation of signalling } \\
\text { pathways after IL- } 6 \text { exposure }\end{array}$} \\
\hline MAP kinase & No phosphorylation & Basic phosphorylation & Increased phosphorylation \\
\hline STAT3 & No phosphorylation & Increased phosphorylation & No phosphorylation \\
\hline Akt & Increased phosphorylation & $\begin{array}{l}\text { Increased phosphorylation } \\
\text { Wegiel et al. (2008) }\end{array}$ & No phosphorylation \\
\hline SOCS-3 & Present & Absent & $?$ \\
\hline $\begin{array}{l}\text { Ligand-independent AR activation } \\
\text { and tumour formation }\end{array}$ & ErbB2 IL-6 not known & IL-6 inhibits & IL-6 stimulates \\
\hline AR & Wild-type & T877A & L701H and T877A \\
\hline
\end{tabular}

number of genes to be similarly regulated by androgen and a compound that activates the PKA pathway. In case of AR activation by the neuropeptide bombesin, it was shown that the addition of bicalutamide to cells stimulated by bombesin causes a negative growth effect (Desai et al. 2006). In addition, 72 genes, most of which are transcription factors and signal transduction proteins, were found to be similarly regulated by androgen and bombesin.

AR activation by IL-6 was first described by Hobisch et al. (1998) and similar results were confirmed by other investigators (Debes et al. 2002). Previous experiments were carried out either in cells transfected with an AR expression vector or in $\mathrm{LNCaP}$ cells that transiently expressed various reporter genes. Variances in levels of reporter gene expression between reports could be a consequence of utilization of different systems to detect AR activity. The levels of reporter gene expression greatly varied, however, the role of the NTD and the MAP kinase pathway in AR activation by IL- 6 seems to be established. Since there is no mutation in the NTD of the MDA PCa $2 b$ AR, it is also not surprising that the effects of IL-6 were detected. We hypothesize that the opposite proliferative responses of AR-positive prostate cancer cells to IL-6 treatment are due to differences in expression of AR coregulators rather than the presence of receptor mutation(s). It has been shown that SRC-1 and p300 cofactors are required for AR activation by IL-6 (Debes et al. 2002, Ueda et al. 2002b). In the presence of a p300 mutant that lacks histone acetylase activity, the effect of IL-6 was greatly diminished (Debes et al. 2002). Under experimental conditions reported by Ueda et al. (2002a), the levels of AR activity in LNCaP induced by IL-6 were much lower than those stimulated by androgen. Nevertheless, the same authors also showed that IL-6 could induce expression of an AR-regulated gene. Those previous results are similar to our data obtained with the MDA PCa $2 b$ AR. Various AR mutations were found in human prostate cancer. It was of our interest to elucidate distinct activation potency of the wild-type $A R$ and the AR with double mutation (L701H and T877A) expressed in LAPC-4 and MDA PCa $2 b$ cells respectively. We confirmed previous findings showing that the wild-type AR was stimulated by androgen to higher levels than the mutated one (Zhao et al. 1999).

We demonstrated that neither MDA PCa $2 \mathrm{~b}$ nor LAPC-4 cells express endogenous IL-6. The lack of IL-6 gene expression was also reported in LNCaP cells, whereas AR-negative PC-3 and DU-145 cells secrete high amounts of the cytokine into the supernatants (Chung et al. 1999). This inverse correlation could be explained by the presence of the AR, since it was shown in bone cell cultures that steroids inhibit expression of IL-6 (Bellido et al. 1995). With aging, serum androgen levels decline while serum IL-6 levels increase (Li et al. 1993). A body of evidence showed that IL- 6 gene can be induced by nuclear factor kappa $\mathrm{B}(\mathrm{NF} \kappa \mathrm{B})$. NF $\mathrm{NB}$ regulates expression of genes involved in cell growth and survival. It has been reported that androgen has an inhibitory effect on

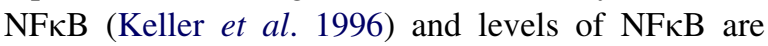
increased in androgen-independent xenografts in comparison to androgen-dependent ones (Chen \& Sawyers 2002). Further studies may be performed in order to investigate whether $\mathrm{NF \kappa B}$ is inactive in MDA PCa $2 b$ and/or LAPC- 4 cells.

Because of its pleiotropic role and increased expression, IL-6 is considered a potential target for therapy in a subgroup of prostate cancer patients. Most studies were carried out with the chimeric monoclonal 
anti-IL-6 antibody CNTO 328. Steiner et al. (2006) showed a partial reduction in tumour growth in nude mice inoculated with LNCaP-IL-6 + cells after CNTO 328 treatment. This effect may be at least in part a consequence of inhibition of expression of the antiapoptotic Mcl-1 gene (Cavarretta et al. 2007). Similar data were obtained when PC-3 and LuCaP 35 xenografts were treated with CNTO 328 (Smith \& Keller 2001, Wallner et al. 2006). Future therapy approaches using the anti-IL-6 antibody may be developed with MDA PCa $2 b$ xenografts grown in the presence of IL-6.

In summary, the major finding of this paper is that IL-6 is able to maintain tumour growth through activation of the AR. Our results suggest that stimulation of in vivo growth by IL-6 may be relevant in a subgroup of prostate cancer patients. Complex regulation of cellular events by IL-6 in AR-positive cell lines is summarized in Table 1. The findings of the present study may therefore improve understanding how IL-6 affects cellular events, such as tumour cell growth in vitro and in vivo through its interaction with the AR pathway and allow development of a more effective experimental therapy based on inhibition of IL-6 action in prostate cancer.

\section{Declaration of interest}

The authors declare no conflict of interest.

\section{Funding}

European Union (Project 'Prostate cancer integrated management approach') and Austrian Science Foundation FWF grant number 19933.

\section{Author contribution statement}

Kamilla Malinowska - performed in vitro studies including proliferation, signal transduction experiments, PCR, reporter gene assays, analyzed data, wrote the first version of the manuscript and corrected it on the basis of discussions with other group members.

Hannes Neuwirt - assisted in proliferation studies, prepared a legal request for animal experiments, designed and performed animal experiments, analyzed data, commented on all versions of the manuscript.

Ilaria $\mathrm{T}$ Cavarretta - provided advice for in vitro experiments, analyzed data, commented on several versions of the manuscript.

Jasmin Bektic - performed animal experiments and commented on the first version of the manuscript.

Hannes Steiner - performed animal experiments and commented on the first version of the manuscript.
Hermann Dietrich - designed animal experiments, analyzed data and commented on several versions of the manuscript.

Patrizia L Moser - collected material from animal experiments, analyzed data and commented on the first version of the manuscript.

Dietmar Fuchs - performed IL-6 measurements, analyzed data and commented on the first version of the manuscript.

Alfred Hobisch - participated in conception of the study, data analysis and commented on the first version of the manuscript.

Zoran Culig - planned the study, led group meetings in which data were discussed, supervized experimental work, corrected drafts of the paper and prepared it for submission.

\section{Acknowledgements}

The authors appreciate helpful advice on animal experiments from Drs V Wenzel, P Hobisch-Hagen and N Navone and Y Jang, laboratory coordinator. Prof P Roy-Burman, Dr J A Nemeth and $\mathrm{H} \mathrm{Bu}$ are acknowledged for helpful suggestions. The authors thank Prof C Sawyers and D Feldman for providing cells and plasmid used in the present study. Astra Zeneca is acknowledged for supply of bicalutamide for the study. Expert technical assistance of G Sierek and E Tafatsch and editorial assistance of $\mathrm{R}$ Schober is gratefully appreciated.

\section{References}

Bakin RE, Gioeli D, Sikes RA, Bissonette EA \& Weber MJ 2003 Constitutive activation of the Ras/mitogen-activated protein kinase signaling pathway promotes androgen hypersensitivity in LNCaP prostate cancer cells. Cancer Research 63 1981-1989.

Bellezza I, Neuwirt H, Nemes C, Cavarretta IT, Puhr M, Steiner H, Minelli A, Bartsch G, Offner F, Hobisch A et al. 2006 Suppressor of cytokine signaling-3 antagonizes cAMP effects on proliferation and apoptosis and is expressed in human prostate cancer. American Journal of Pathology 169 2199-2208.

Bellido T, Jilka RL, Boyce BF, Girasole G, Broxmeyer H, Dalrymple SA, Murray R \& Manolagas SC 1995

Regulation of interleukin-6, osteoclastogenesis, and bone mass by androgens. The role of the androgen receptor. Journal of Clinical Investigation 95 2886-2895.

Bradford M 1978 A rapid and sensitive method for the quantitation of microgram quantities of protein using the principle of protein-dye binding. Analytical Biochemistry 72 248-254.

Buchanan G, Greenberg NM, Scher HI, Harris JM, Marshall VR \& Tilley WD 2001 Collocation of androgen receptor gene mutations in prostate cancer. Clinical Cancer Research 7 1273-1281.

Cavarretta IT, Neuwirt H, Untergasser G, Moser PL, Zaki MH, Steiner H, Rumpold H, Fuchs D, Hobisch A, Nemeth JA 
et al. 2007 The antiapoptotic effect of IL-6 autocrine loop in a cellular model of advanced prostate cancer is mediated by Mcl-1. Oncogene 26 2822-2832.

Chen CD \& Sawyers CL 2002 NF-kappa B activates prostatespecific antigen expression and is upregulated in androgen-independent prostate cancer. Molecular and Cellular Biology 22 2862-2870.

Chen RH, Chang MC, Su YH, Tsai YT \& Kuo ML $1999 a$ Interleukin-6 inhibits transforming growth factor-betainduced apoptosis through the phosphatidylinositol 3-kinase/Akt and signal transducers and activators of transcription 3 pathways. Journal of Biological Chemistry 274 23013-23019.

Chen T, Cho RW, Stork PJ \& Weber MJ $1999 b$ Elevation of cyclic adenosine $3^{\prime} 5^{\prime}$-monophosphate potentiates activation of mitogen-activated protein kinase by growth factors in LNCaP prostate cancer cells. Cancer Research 59 213-218.

Chen T, Wang LH \& Farrar WL 2000 Interleukin 6 activates androgen receptor-mediated gene expression through a signal transducer and activator of transcription 3-dependent pathway in LNCaP prostate cancer cells. Cancer Research 60 2132-2135.

Chen S-C, Chang YL, Ling Wang D \& Cheng J-J 2006 Herbal remedy magnolol suppresses IL-6 induced STAT3 activation and gene expression in endothelial cells. British Journal of Pharmacology 148 226-232.

Chung TD, Yu JJ, Spiotto MT, Bartkowski M \& Simons JW 1999 Characterization of the role of IL-6 in the progression of prostate cancer. Prostate 38 199-207.

Craft N, Shostak Y, Carey M \& Sawyers CL 1999 A mechanism for hormone-independent prostate cancer through modulation of androgen receptor signaling by the HER-2/neu tyrosine kinase. Nature Medicine 5 280-285.

Culig Z, Hobisch A, Cronauer MV, Cato AC, Hittmair A, Radmayr C, Eberle J, Bartsch G \& Klocker H 1993 Mutant androgen receptor detected in an advanced-stage prostatic carcinoma is activated by adrenal androgens and progesterone. Molecular Endocrinology 7 1541-1550.

Culig Z, Hobisch A, Cronauer MV, Radmayr C, Trapman J, Hittmair A, Bartsch G \& Klocker H 1994 Androgen receptor activation in prostatic tumor cell lines by insulinlike growth factor-I, keratinocyte growth factor, and epidermal growth factor. Cancer Research 54 5474-5478.

Culig Z, Hoffmann J, Erdel M, Eder IE, Hobisch A, Hittmair A, Bartsch G, Utermann G, Schneider MR, Parczyk K et al. 1999 Switch from antagonist to agonist of the androgen receptor blocker bicalutamide is associated with prostate tumour progression in a new model system. British Journal of Cancer 81 242-251.

Culig Z, Steiner H, Bartsch G \& Hobisch A $2005 a$ Interleukin-6 regulation of prostate cancer cell growth. Journal of Cellular Biochemistry 95 497-505.

Culig Z, Steiner H, Bartsch G \& Hobisch A $2005 b$ Mechanisms of endocrine therapy-reponsive and -unresponsive prostate tumours. Endocrine-Related Cancer 12 229-244.
Daeipour M, Kumar G, Amaral MC \& Nel AE 1993

Recombinant IL-6 activates p42 and p44 mitogenactivated protein kinases in the IL-6 responsive B cell line, AF-10. Journal of Immunology 150 4743-4753.

Debes JD, Schmidt LJ, Huang H \& Tindall DJ 2002 p300 mediates androgen-independent transactivation of the androgen receptor by interleukin 6. Cancer Research 62 5632-5636.

Degeorges A, Tatoud R, Fauvel-Lafeve F, Podgorniak MP, Millot G, de Cremoux P \& Calvo F 1996 Stromal cells from human benign prostate hyperplasia produce a growth-inhibitory factor for LNCaP prostate cancer cells, identified as interleukin-6. International Journal of Cancer 68 207-214.

Desai SJ, Ma AH, Tepper CG, Chen HW \& Kung HJ 2006 Inappropriate activation of the androgen receptor by nonsteroids: involvement of the Src kinase pathway and its therapeutic implications. Cancer Research 66 1044910459.

Dong JT 2006 Prevalent mutations in prostate cancer. Journal of Cellular Biochemistry 97 433-447.

Ernst M, Oates A \& Dunn AR 1996 Gp130-mediated signal transduction in embryonic stem cells involves activation of Jak and Ras/mitogen-activated protein kinase pathways. Journal of Biological Chemistry 271 3013630143.

Franco OE, Onishi T, Yamakawa K, Arima K, Yanagawa M, Sugimura Y \& Kawamura J 2003 Mitogen-activated protein kinase pathway is involved in androgen-independent PSA gene expression in LNCaP cells. Prostate 56 319-325.

Godoy-Tundidor S, Cavarretta IT, Fuchs D, Fiechtl M, Steiner H, Friedbichler K, Bartsch G, Hobisch A \& Culig Z 2005 Interleukin-6 and oncostatin M stimulation of proliferation of prostate cancer $22 \mathrm{Rv} 1$ cells through the signaling pathways of p38 mitogen-activated protein kinase and phosphatidylinositol 3-kinase. Prostate 64 209-216.

Hara T, Miyazaki J, Araki H, Yamaoka M, Kanzaki N, Kusaka M \& Miyamoto M 2003 Novel mutations of androgen receptor: a possible mechanism of bicalutamide withdrawal syndrome. Cancer Research 63 149-153.

Heinrich PC, Behrmann I, Haan S, Hermanns HM, MüllerNeven G \& Schaper F 2003 Principles of interleukin (IL)6-type cytokine signalling and its regulation. Biochemical Journal 374 1-20.

Hobisch A, Eder IE, Putz T, Horninger W, Bartsch G, Klocker H \& Culig Z 1998 Interleukin-6 regulates prostate-specific protein expression in prostate carcinoma cells by activation of the androgen receptor. Cancer Research 58 4640-4645.

Hobisch A, Ramoner R, Fuchs D, Godoy-Tundidor S, Bartsch G, Klocker H \& Culig Z 2001 Prostate cancer cells (LNCaP) generated after long-term interleukin-6 (IL-6) treatment express IL-6 and acquire an IL-6 partially resistant phenotype. Clinical Cancer Research 7 2941-2948. 
Horiguchi A, Oya M, Marumo K \& Murai M 2002 STAT3, but not ERKs, mediates the IL-6-induced proliferation of renal cancer cells. Kidney International 61 926-938.

Huggins C, Stevens RE \& Hodges CV 1941 Studies on prostatic cancer. II. The effects of castration on advanced carcinoma of the prostate gland. Archives of Surgery 43 209-223.

Keller ET, Chang C \& Ershler WB 1996 Inhibition of NFkappaB activity through maintenance of IkappaBalpha levels contributes to dihydrotestosterone-mediated repression of the interleukin-6 promoter. Journal of Biological Chemistry 271 26267-26275.

Kitamura H, Okamoto S, Shimamoto Y, Morimatsu M, Terao A \& Saito M 1998 Central IL-1 differentially regulates peripheral IL-6 and TNF synthesis. Cellular and Molecular Life Sciences 54 282-287.

Klein KA, Reiter RE, Redula J, Moradi H, Zhu XL, Brothman AR, Lamb DJ, Marcelli M, Belldegrun A, Witte ON et al. 1997 Progression of metastatic human prostate cancer to androgen independence in immunodeficient SCID mice. Nature Medicine 3 402-408.

Kohase M, Henriksen-DeStefano D, May LT, Vilcek J \& Sehgal PB 1986 Induction of beta 2-interferon by tumor necrosis factor: a homeostatic mechanism in the control of cell proliferation. Cell 45 659-666.

Kopantzev Y, Heller M, Swaminathan N \& Rudikoff S 2002 IL-6 mediated activation of STAT3 bypasses Janus kinases in terminally differentiated B lineage cells. Oncogene 21 6791-6800.

Kreis S, Munz GA, Haan S, Heinrich PC \& Behrmann I 2007 Cell density dependent increase of constitutive signal transducers and activators of transcription 3 activity in melanoma cells is mediated by Janus kinases. Molecular Cancer Research 5 1331-1341.

Lee LF, Guan J, Qiu Y \& Kung HJ 2001 Neuropeptideinduced androgen independence in prostate cancer cells: roles of nonreceptor tyrosine kinases Etk/Bmx, Src, and focal adhesion kinase. Molecular and Cellular Biology 21 8385-8397.

Li ZG, Danis VA \& Brooks PM 1993 Effect of gonadal steroids on the production of IL-1 and IL- 6 by blood mononuclear cells in vitro. Clinical and Experimental Rheumatology 11 157-162.

Marcelli M, Ittmann M, Mariani S, Sutherland R, Nigam R, Murthy L, Zhao Y, DiConcini D, Puxeddu E, Esen A et al. 2000 Androgen receptor mutations in prostate cancer. Cancer Research 60 944-949.

Moran DM, Mattocks MA, Cahill PA, Koniaris LG \& McKillop IH 2008 Interleukin-6 mediates G(0)/G(1) arrest in hepatocellular carcinoma through a STAT3dependent pathway. Journal of Surgical Research 147 23-33.

Mori S, Murakami-Mori K \& Bonavida B 1999 Interleukin-6 induces G1 arrest through induction of p27(Kip1), a cyclin-dependent kinase inhibitor, and neuron-like morphology in LNCaP prostate tumor cells. Biochemical and Biophysical Research Communications 257 609-614.
Nakafuku M, Satoh T \& Kaziro Y 1992 Differentiation factors, including nerve growth factor, fibroblast growth factor, and interleukin-6, induce an accumulation of an active Ras.GTP complex in rat pheochromocytoma PC12 cells. Journal of Biological Chemistry 267 19448-19454.

Nakashima J, Tachibana M, Horiguchi Y, Oya M, Ohigashi T, Asakura H \& Murai M 2000 Serum interleukin 6 as a prognostic factor in patients with prostate cancer. Clinical Cancer Research 6 2702-2706.

Navone NM, Olive M, Ozen M, Davis R, Troncoso P, Tu SM, Johnston D, Pollack A, Pathak S, von Eschenbach AC et al. 1997 Establishment of two human prostate cancer cell lines derived from a single bone metastasis. Clinical Cancer Research 3 2493-2500.

Nazareth LV \& Weigel NL 1996 Activation of the human androgen receptor through a protein kinase A signaling pathway. Journal of Biological Chemistry 271 19900-19907.

Papatsoris AG, Karamouzis MV \& Papavassiliou AG 2007 The power and promise of 'rewiring' the mitogenactivated protein kinase network in prostate cancer therapeutics. Molecular Cancer Therapeutics 6 811-819.

Putz T, Culig Z, Eder IE, Nessler-Menardi C, Bartsch G, Grunicke H, Überall F \& Klocker H 1999 Epidermal growth factor receptor blockade inhibits the action of EGF, insulin-like growth factor I, and a protein kinase A activator on the mitogen-activated protein kinase pathway in prostate cancer cell lines. Cancer Research 59 227-233.

Seaton A, Scullin P, Maxwell PJ, Wilson C, Pettigrew J, Gallagher R, O'Sullivan JM, Johnston PG \& Waugh DJ 2008 Interleukin-8 signaling promotes androgen-independent proliferation of prostate cancer cells via induction of androgen receptor expression and activation.

Carcinogenesis 29 1148-1156.

Smith PC \& Keller ET 2001 Anti-interleukin-6 monoclonal antibody induces regression of human prostate cancer xenografts in nude mice. Prostate 48 47-53.

Sortino MA, Condorelli F, Vancheri C, Chiarenza A, Bernardini R, Consoli U \& Canonico PL 2000 Mitogenic effect of nerve growth factor (NGF) in LNCaP prostate adenocarcinoma cells: role of the high- and low-affinity NGF receptors. Molecular Endocrinology 14 124-136.

Spiotto MT \& Chung TD 2000 STAT3 mediates IL-6induced growth inhibition in the human prostate cancer cell line LNCaP. Prostate 42 88-98.

Steiner H, Godoy-Tundidor S, Rogatsch H, Berger AP, Fuchs D, Comuzzi B, Bartsch G, Hobisch A \& Culig Z 2003 Accelerated in vivo growth of prostate tumors that up-regulate interleukin-6 is associated with reduced retinoblastoma protein expression and activation of the mitogen-activated protein kinase pathway. American Journal of Pathology 162 655-663.

Steiner H, Cavarretta IT, Moser PL, Berger AP, Bektic J, Dietrich H, Zaki MH, Nakada M, Hobisch A, Nemeth JA et al. 2006 Regulation of growth of prostate cancer cells 
selected in the presence of interleukin- 6 by the antiinterleukin-6 antibody CNTO 328. Prostate 66 1744-1752.

Suzuki H, Sato N, Watabe Y, Masai M, Seino S \& Shimazaki J 1993 Androgen receptor gene mutations in human prostate cancer. Journal of Steroid Biochemistry and Molecular Biology 46 759-765.

Ueda T, Bruchovsky N \& Sadar MD $2002 a$ Activation of the androgen receptor N-terminal domain by interleukin- 6 via MAPK and STAT3 signal transduction pathways. Journal of Biological Chemistry 277 7076-7085.

Ueda T, Mawji NR, Bruchovsky N \& Sadar MD $2002 b$ Ligand-independent activation of the androgen receptor by interleukin- 6 and the role of steroid receptor coactivator-1 in prostate cancer cells. Journal of Biological Chemistry 277 38087-38094.

Wallner L, Dai J, Escara-Wilke J, Zhang J, Yao Z, Lu Y, Trikha M, Nemeth JA, Zaki MH \& Keller ET 2006 Inhibition of interleukin-6 with CNTO328, an antiinterleukin-6 monoclonal antibody, inhibits conversion of androgen-dependent prostate cancer to an androgenindependent phenotype in orchiectomized mice. Cancer Research 66 3087-3095.
Wang Q, Horiatis D \& Pinski J 2004 Interleukin-6 inhibits the growth of prostate cancer xenografts in mice by the process of neuroendocrine differentiation. International Journal of Cancer 111 508-513.

Wang G, Jones SJ, Marra MA \& Sadar MD 2006 Identification of genes targeted by the androgen and PKA signaling pathways in prostate cancer cells. Oncogene $\mathbf{2 5}$ 7311-7323.

Wegiel B, Bjartell A, Culig Z \& Persson JL 2008 Interleukin-6 activates PI3K/Akt pathway and regulates cyclin A1 to promote prostate cancer cell survival. International Journal of Cancer 122 1521-1529.

Yang L, Wang L, Lin HK, Kan PY, Xie S, Tsai MY, Wang PH, Chen YT \& Chang C 2003 Interleukin-6 differentially regulates androgen receptor transactivation via PI3K-Akt, STAT3, and MAPK, three distinct signal pathways in prostate cancer cells. Biochemical and Biophysical Research Communications 305 462-469.

Zhao XY, Boyle B, Krishnan AV, Navone NM, Peehl DM \& Feldman D 1999 Two mutations identified in the androgen receptor of the new human prostate cancer cell line MDA PCa 2a. Journal of Urology 162 2192-2199. 